\title{
Attitudes and Beliefs of COVID-19 and Vaccine Uptake among Amish Women ${ }^{1}$
}

\author{
Melissa Thomas \\ Assistant Professor, Department of Primary Care \\ Ohio University Heritage College of Osteopathic Medicine \\ Founding Director \\ Center for Appalachia Research in Cancer Education \\ thomasm5@ohio.edu \\ Iva Byler \\ Center for Appalachia Research in Cancer Education \\ Kayla Marrero \\ Center for Appalachia Research in Cancer Education \\ Janet Miller \\ Center for Appalachia Research in Cancer Education \\ Joseph F. Donnermeyer \\ Emeritus Professor/Academy Professor \\ School of Environment and Natural Resources \\ The Ohio State University \\ donnermeyer.1@gmail.com
}

\begin{abstract}
The Amish, a Christian religious group living in rural areas with distinct beliefs about remaining separate from the outside world, have communities in 31 states and four Canadian provinces with just over 600 settlements. Their access to health care and technology is often limited. Several studies have noted low vaccination rates for preventable diseases among the Amish, often due to lack of knowledge about efficacy and safety of vaccines. To gain an understanding of beliefs surrounding COVID-19 and attitudes toward vaccine uptake, we surveyed 863 Amish and Mennonite women throughout Ohio who participated in rural mobile health clinics between 2015 and 2019 at two time periods: before and after the 2020 election. We received 372 completed surveys, 252 of which were completed by respondents who identified themselves as Amish. While $100 \%$ of the Amish respondents had heard of COVID-19 and $90 \%$ reported knowing someone who had contracted the disease, a mere $1.7 \%$ (4) indicated a willingness to get vaccinated. In terms of COVID-19 diagnosis, post-election participants were two times more likely to report having a positive test than pre-election respondents $(p=.011)$. Qualitative analyses revealed significant differences in keywords used to describe COVID-19. Post-election respondents were less likely to use words like "evil" and "bad" and associate COVID-19 with the flu. A notable shift in vaccine hesitancy among Amish participants centered on the perceived politicization of the pandemic and safety/efficacy of the vaccines. Public health efforts should center on raising awareness of the severity of COVID-19 and the benefits of vaccine uptake for distinctive subcultures like the Amish.
\end{abstract}

\footnotetext{
${ }^{1}$ The authors would like to thank the Amish and Mennonite women who participated in the study, plus the bishops and other Amish leaders and community members who supported it. 
Submitted May 10, 2021; accepted July 23, 2021; published October 8, 2021

https://doi.org/10.18061/jpac.v2i1.8310

Keywords: Amish, COVID-19, vaccine

\section{Introduction}

The Amish are a rural-located religious subculture, with beliefs and practices that are quite distinctive from North American society, including reliance on horse-and-buggy travel, use of the Pennsylvania Dutch language in everyday conversation, and selective use of technology (Kraybill et al., 2013). They are also known as a religious group who, for a variety of reasons, displays historically low rates of vaccine immunizations for such illnesses as polio, rubella, and pertussis, among others (Alexander et al., 2009; Briss et al., 1992; Fry et al., 2001; Gastanaduy et al., 2016; Grabenstein, 2013; Kettunen et al., 2017; Medina-Marino et al., 2013; Myers et al., 2017; Scott et al., 2021; Wenger et al., 2011; Williamson et al., 2017; Yoder \& Dworkin, 2006).

Amish origins harken back to the early years of the Protestant Reformation of sixteenth-century Europe (Nolt, 2015), but their sociocultural character is shaped largely by their North American experience, a journey that began with the first Amish immigrant arrivals early on in the eighteenth century. Of specific importance to the demographic context within which to examine issues associated with possible spread of diseases and vaccination rates is that over the past five decades, the Amish population has surged, with an estimated doubling time of about 20 to 22 years (Donnermeyer, 2021).

Accompanying this rapid increase is an expansion in the number of Amish communities such that today Amish can be found in 31 states and four Canadian provinces. Amish communities are clusters of Amish families who live close enough to one other for worship and other forms of socializing through the use of horse-and-buggy travel (Kraybill et al., 2013). Today there are about 600 communities, ranging in size from newly established communities of only a handful of families to a few communities with over 100 church groups, thousands of Amish households, and an even larger number of tourists (Kraybill et al., 2013). All but a couple dozen communities are small, interspersed with many non-Amish neighbors, who far outnumber the Amish themselves.

The Amish are a Christian sectarian group without a centralized hierarchy of religious offices (Wilson, 1982; Stark \& Bainbridge, 1979). All but a handful of Amish church groups or church districts, of which there are about 2,700, are small (about two to three dozen families). Each nominates its own church leaders (bishop, minister, and deacon). The Amish are highly congregational in decision-making; baptized members of each church group normally review their church discipline twice each year before their semiannual communion service. This is when changes to the church discipline (known in Pennsylvania Dutch as the Ordnung or "order"), such as adoption of new technologies and modification of practices, can be made (Kraybill et al., 2013). Regular Sunday services are held biweekly, with services rotated from residence to residence of members within the church group. The fellowship meal after the Sunday service is an important gathering time for discussions about issues, including those related to health. 
The Amish are a high fertility group, with religious beliefs that help sustain a value for large families (Greksa, 2002; Wasao \& Donnermeyer, 1996). As well, they are considered to have a high density of acquaintance through extended family and various social networks that bring an unusually high level of cohesion within their communities and outward to family and friends living in other settlements (Freudenburg, 1986). Visiting is a primary mode for this socializing, with frequent traveling for various family events, auctions, and other special occasions, from weddings to funerals (Hurst \& McConnell, 2010; Kraybill et al., 2013). Within these social networks, news from outside the Amish subculture can travel very fast, especially news about current events and politics from non-Amish neighbors.

The reason for the historically lower rates of vaccination among the Amish is due to a complex of factors. As Kraybill et al. (2013) observed, "[T]he question of vaccination drives a complicated conversation" (p. 345). One of the most important sources of influence is the belief that medical decisions of all kinds are primarily the responsibility of the family (Hostetler, 1993; Hurst \& McConnell, 2010). Hence, it is up to the parents to decide if vaccinations are appropriate for themselves and their children.

Another factor can be described by a well-known phrase that is frequently cited in a variety of social science disciplines to understand both conforming and deviant behavior: "peer pressure" (Henslin, 2015). Even though peer pressure is commonly thought of as a sociological phenomenon associated with adolescence, it is important throughout the life course. One form of peer pressure is the Amish church group to which a family belongs and the associated church discipline or Ordnung. One's church group influences decision-making across a wide range of issues and is an important source of conformity. As a reference group (Heaton, 1986), other families in the same church group will likely influence decision-making about vaccinations specifically, and about medical care more generally. Likewise, in Amish settlements with more than one church group, awareness of what other church districts are doing can create an additional layer of peer pressure about actions to be taken on medical care alternatives.

Amish media, such as periodicals like The Budget, Die Botschaft, and The Diary, among others, also influence what Amish people know about various medical issues. Complicating the conversation even more are non-Amish sources of information, such as non-Amish neighbors, tourists who patronize Amish businesses (Kraybill et al., 2013), and even news broadcasts from the radios of non-Amish van drivers who transport Amish customers to and from various services in nearby towns and to other Amish communities at greater distances for weddings, funerals, and visiting. It may be surprising to the public, and even to many scholars, but the church Ordnung and the views of ordained men are considered relatively minor influences on Amish attitudes about vaccinations (Fry et al., 2001; Hostetler, 1993; Kettunen et al., 2017; Kraybill et al., 2013).

Gaining insight into Amish views about COVID-19 adds to knowledge from past studies of barriers related to their relative reluctance to accept immunization and vaccines. Hence, one research objective of this study is to examine Amish responses to COVID-19 vaccinations during the midst of the pandemic. The origins of the COVID-19 virus, wearing of masks, and efficacy of vaccinations became more politicized by the presidential election of 2020 (Clinton et al., 2021; 
Naeim et al., 2021). A second research objective, therefore, was to examine whether Amish attitudes about COVID-19 were different before and after the election on November 3, 2020.

Given their large families, rapid population increase and settlement expansion, strong family and social networks, and growing contact with non-Amish, especially tourists, through Amishowned businesses, Amish views about immunization are now more important than in the past. Briss et al. (1992) described the Amish as "geographically diverse but an epidemiologically linked population" (p. 959). Another point of significance related to this study is that low immunization rates among the Amish and other special populations potentially form a reservoir of infection that may eventually break out again into the larger population (Kettunen et al., 2017).

\section{Methods}

To gain an understanding of beliefs and practices concerning COVID-19 among Amish and Mennonite communities in Ohio, we added 10 questions to an existing women's health survey that we previously disseminated to all women who participated in mobile women's health clinics between 2017 and 2019. In partnership with the community-led program called Project Hoffnung (German for "hope"), these no-cost or reduced-cost clinics provide mobile mammography, clinical breast exams, Pap tests and pelvic exams for Amish and Mennonite women throughout rural and Appalachia Ohio in some of the most resource-starved sections of the state. A total of 863 women received the survey. All but 31 had telephone numbers listed in our contact information. If a phone number was available, the woman received a phone call from a trained community coordinator fluent in Pennsylvania Dutch who invited her to participate via phone or mail. Those requesting a mailed copy and those for whom we did not have phone numbers were sent the survey. We divided the participants into two groups. Women who had not participated in one of our screenings since 2017 or 2018 received surveys in August $2020(n=494)$. Women who had participated in a screening during 2019 received surveys in November $2020(n=369)$. Initially, only women who had a two- to three-year gap in screening participation were selected for the health survey, but when COVID-19 hit and our clinics had to be canceled, we then added the 2019 participants to the second survey distribution since no women's health services were provided in 2020.

We asked participants if they have heard of the coronavirus or COVID-19 and if they thought it was a serious disease (yes, no, not sure). We then asked four related questions: Is there spread of COVID-19 in your area? Do you know anyone who was sick? What is your relationship to the sick person? How was the person diagnosed? Relationships included immediate family members, relatives, friends, church members, neighbors, self, and other. Responses to diagnosis were adapted from the Coronavirus Health and Impact Survey (CRISIS) (Nikolaidis et al., 2020) and included the following six options: (1) positive test; (2) diagnosed by doctor or nurse practitioner but did not have a test; (3) diagnosed by doctor or nurse practitioner and had a positive test; (4) have or had possible symptoms, but no diagnosis from a doctor or nurse practitioner; (5) no test; and (6) other. We asked about vaccine uptake when available and included three open-ended questions: Why do you want to get vaccinated or why not? What are your thoughts about the coronavirus? Do you have any other comments? 
We also collected demographic information: age, religious affiliation (Amish, Mennonite, or neither), highest level of education completed (8th grade, high school, some college, college, postgraduate, other), county, years in the county, insurance status and type (no insurance, private insurance, Amish/Church Aid, Medicare, Medicaid, other), and marital status (single, married, living with partner, divorced, widowed). An additional section on breast cancer screening and family history was also part of the survey but was not included in this analysis.

A total of 373 participants completed the survey, a $46 \%$ response rate. Two-thirds (252) of the participants identified as Amish, 118 as Mennonite, and three as English (the Amish term for nonAmish people). The three English participants were eliminated from the study. All but 59 completed surveys were completed via mail, and phone surveys were completed in both English and Pennsylvania Dutch. We chose to delineate our data between two points in time: those who completed the survey before the November 2020 election and those who completed it after the election. That division was possible only for the participants in the second wave of surveys.

There was no significant difference between the distribution of Amish and Mennonite participants who completed the survey between the two groups $(p=.201)$. Specifically, the number of Amish participants was almost identical between pre- and post-election time periods (129, $34.9 \%$ vs. $123,33.2 \%$, respectively). While not statistically significant, it is still true that more individuals who identified as Mennonite completed the survey during the post-election time period $(52,14.7 \%$ vs $66,17.8 \%$ respectively). Given the diverse cultural and religious differences among the many Amish and Mennonite churches and settlements in the 41 counties represented in the sample, for the focus of this article, we chose to limit our analysis to the self-identified Amish members.

We conducted descriptive statistics on all variables and chi-square tests of independence to compare the demographic variables across the two election categories (pre- vs. post-). We also calculated odds ratios between the COVID-19 questions and pre- and post-election completion periods using SPSS 27.0 for all statistical analyses. While an odds ratio is customarily calculated in a logistic regression analysis, it can also be used in a $2 \times 2$ frequency table to determine the significance of a relationship between two variables (Bland \& Altman, 2000). Finally, we conducted a thematic analysis of the open-ended responses using an inductive approach following the six steps identified by Clarke and Braun (2017). Three coders (MT, KM, and JM) read all responses, developed a codebook for manual coding of the data, and met periodically to identify emergent codes and compare coding using a consensus coding process (Huberman \& Miles, 2002).

\section{Results}

Two hundred fifty-two women with a mean age of 57 identified as Amish and completed the survey between September 9, 2020, and February 9, 2021. The age range was between 27 and 86 years, and a little over half (140, or 55.6\%) were 50 to 64 years of age (Table 1). The age range was expected given that most women who attend the women's health screenings are over 40 years of age so that they can participate in the mobile mammography program. There were no significant differences between pre- and post-election demographics (Table 1). Ninety-eight (38.9\%) 
participants completed the survey pre-election with 154 (61.1\%) completing the survey postelection. Of all respondents, 247 (98.4\%) reported an education level of 8th grade or less, and 226 (94.6\%) were married. One hundred forty (57.4\%) respondents had insurance, of which 129 (53.1\%) were insured by community-organized Amish/Church Aid, which provides monetary assistance in the case of medical catastrophes.

Table 1

Characteristics of Survey Participants by Survey Completion Date

\begin{tabular}{|c|c|c|c|}
\hline Demographics & $\begin{array}{l}\text { Pre-election } \\
\begin{array}{c}(N=98) \\
n(\%)^{a}\end{array}\end{array}$ & $\begin{array}{c}\text { Post-election } \\
(N=154) \\
n(\%)^{a}\end{array}$ & $p^{b}$ \\
\hline Age category (in years) & & & .121 \\
\hline$<50$ & $25(25.5)$ & $26(16.9)$ & \\
\hline $50-64$ & $47(48.0)$ & $93(60.4)$ & \\
\hline $65+$ & $26(26.5)$ & $35(22.7)$ & \\
\hline \multicolumn{4}{|l|}{ Education } \\
\hline 8th grade or less & $94(96.9)$ & $153(99.4)$ & \\
\hline High school/GED & $1(1.0)$ & $1(0.6)$ & \\
\hline Some college & $1(1.0)$ & $0(0.0)$ & \\
\hline Other & $1(1.0)$ & $0(0.0)$ & \\
\hline Marital status & & & .998 \\
\hline Married & $87(94.6)$ & $139(94.6)$ & \\
\hline Single & $5(5.4)$ & $8(5.4)$ & \\
\hline Insurance & & & .607 \\
\hline Insured & $52(55.3)$ & $88(58.7)$ & \\
\hline Private insurance & $4(4.3)$ & $0(0.0)$ & \\
\hline Amish/Church Aid & $44(46.8)$ & $85(57.0)$ & \\
\hline Medicare & $1(1.1)$ & $0(0.0)$ & \\
\hline Medicaid & $3(3.2)$ & $1(0.7)$ & \\
\hline Other & $0(0.0)$ & $2(1.3)$ & \\
\hline No insurance & $42(44.7)$ & $61(40.9)$ & \\
\hline
\end{tabular}

a Percentages are based on non-missing values. ${ }^{\mathrm{b}} p$ for the chi-square test comparing participants who completed the survey pre-election vs. post-election.

We asked respondents questions about COVID-19 and compared pre- and post-election responses to look for significance (Table 2). When asked if they had heard of the coronavirus or COVID-19, 100\% of respondents said yes. We found significant differences between acknowledged spread of COVID-19 in the community and survey completion date, with 67 $(60.9 \%)$ of post-election participants reporting community spread of the virus while only 17 $(21.2 \%)$ of pre-election participants reported the same $(p<.001)$. One hundred ninety-nine $(89.6 \%)$ said they knew someone who had been sick with COVID-19. When we asked participants 
to denote the closest relation of the people they knew who were sick with COVID-19, 87 (34.7\%) reported an immediate family member, $100(39.8 \%)$ knew a relative, $63(25.1 \%)$ reported a friend, $79(31.5 \%)$ knew a church member, 51 (20.3\%) reported a neighbor, and $67(26.7 \%)$ reported themselves. We found post-election respondents significantly more likely to report COVID-19 illnesses in the categories of "neighbor" $(p=<.001)$ and "myself" $(p=.007)$. Forty-two (27.5\%) post-election participants knew a neighbor with COVID-19, while only nine $(9.2 \%)$ pre-election participants reported a neighbor. Similarly, 50 (32.7\%) of the post-election respondents had COVID-19 themselves but only 17 (17.3\%) of pre-election participants did.

Table 2

Odds Ratio Table Comparing Election Status and COVID-19 Questions

\begin{tabular}{|c|c|c|c|}
\hline \multirow[b]{2}{*}{ Question } & \multicolumn{3}{|c|}{ Pre-Election vs. Post-Election } \\
\hline & OR & $95 \% \mathrm{Cl}$ & $p$ \\
\hline $\begin{array}{l}\text { Do you believe that the coronavirus or COVID-19 is a } \\
\text { serious disease? }\end{array}$ & 1.533 & {$[.802,2.929]$} & .195 \\
\hline $\begin{array}{l}\text { Is there a spread of coronavirus or COVID-19 in the } \\
\text { community where you are living? }\end{array}$ & 5.800 & {$[3.040,11.066]$} & $<.001^{* *}$ \\
\hline $\begin{array}{l}\text { Do you know anybody who has been sick with the } \\
\text { coronavirus or COVID-19? }\end{array}$ & 2.060 & {$[.861,4.928]$} & .099 \\
\hline \multicolumn{4}{|l|}{ If yes, what was their closest relation to you? } \\
\hline Immediate family member & 1.697 & {$[.980,2.938]$} & .058 \\
\hline Relative & 1.003 & {$[598,1.684]$} & .991 \\
\hline Friend & 1.525 & {$[.833,2.791]$} & .170 \\
\hline Church member & 1.593 & {$[.908,2.795]$} & .103 \\
\hline Neighbor & 3.742 & {$[1.729,8.098]$} & $<.001^{* *}$ \\
\hline Myself & 2.313 & {$[1.241,4.310]$} & $.007^{* *}$ \\
\hline \multicolumn{4}{|l|}{ How was the person diagnosed with the coronavirus? } \\
\hline Positive test & 2.162 & {$[1.184,3.950]$} & $.011^{*}$ \\
\hline $\begin{array}{l}\text { Diagnosed by doctor or nurse practitioner, but did not } \\
\text { have a test }\end{array}$ & 1.759 & {$[.455,6.799]$} & .407 \\
\hline $\begin{array}{l}\text { Diagnosed by doctor or nurse practitioner and had a } \\
\text { positive test }\end{array}$ & 1.142 & {$[.571,2.284]$} & .708 \\
\hline $\begin{array}{l}\text { Have or had possible symptoms, but no diagnosis } \\
\text { from a doctor or nurse practitioner and no test }\end{array}$ & 1.550 & {$[.922,2.606]$} & .098 \\
\hline
\end{tabular}

Note. $\mathrm{Cl}=$ confidence interval.

${ }^{*} p<.05 .{ }^{* *} p<.01$.

Along with closest relation, we also asked participants which diagnostic method was used to confirm illness with COVID-19 (Table 2). Across all participants, 71 (28.4\%) chose "positive test" as the means of diagnosis, $11(4.4 \%)$ were diagnosed by a health care provider without a positive test, $41(16.4 \%)$ were diagnosed by a health care provider with a positive test, and $108(43.2 \%)$ had symptoms of COVID-19 but were not diagnosed. Diagnosis by positive test was the only 
diagnostic method that showed significant variance based on election status. Post-election participants $(n=52,34.2 \%)$ were two times more likely to report having a positive test than preelection respondents $(n=19,19.4 \% ; p=.011)$.

We analyzed the common themes seen in qualitative responses to COVID-19 questions for significant differences based on pre- or post-election status (Table 3). We found that post-election respondents were significantly less likely to relate COVID-19 with the flu $(p=.004)$ and less likely to use words like "evil" and "bad" in their responses $(p=.021)$. Additionally, post-election respondents were significantly less likely to comment on COVID-19 being blown out of proportion $(p=.014)$; these comments often included the word "media," which was mentioned 14 times across all respondents (Table 4). Interestingly, those who self-identified as having been sick with COVID19 were also significantly less likely to mention "blown" in their comments about COVID-19 $(\mathrm{OR}=.337, .161, .705, p=.003)$, with one woman stating, "At first I believed the virus was blown up but when I got it and was so very sick \& ended up in the hospital, I realized it was a VERY REAL serious virus."

\section{Table 3}

Odds Ratio Table Comparing Election Status and Qualitative Themes Regarding COVID-19 Questions

\begin{tabular}{lccc}
\hline & \multicolumn{3}{c}{ Pre-Election vs. Post-Election } \\
\cline { 2 - 4 } Theme & OR & $95 \% \mathrm{Cl}$ & $p$ \\
\hline Faith & 1.064 & {$[.570,1.985]$} & .846 \\
Politics & .626 & {$[.310,1.261]$} & .187 \\
Flu & .435 & {$[.245, .773]$} & $.004^{* *}$ \\
Blown & .503 & {$[.289, .875]$} & $.014^{*}$ \\
Fear & 1.070 & {$[.498,2.299]$} & .863 \\
Masks & .844 & {$[.402,1.774]$} & .650 \\
Chip & .401 & {$[.138,1.164]$} & .084 \\
Media & 1.632 & {$[.497,5.355]$} & .415 \\
Cure & .634 & {$[.039,10.255]$} & .746 \\
Evil, Bad & .264 & {$[.079, .881]$} & $.021^{*}$ \\
Mistrust & 1.230 & {$[.619,2.441]$} & .554 \\
\hline
\end{tabular}

Note. $\mathrm{Cl}=$ confidence interval.

${ }^{*} p<.05 .{ }^{* *} p<.01$.

Additionally, we found some differences in the number of times a qualitative theme was mentioned pre- vs. post-election. Even though the differences were not significant, they were nonetheless, interesting (Table 4). Pre-election respondents mentioned politics 18 times (18.4\%) and made comments such as "I'm wondering if a lot of this is political \& will blow over after the election is over" and, "[It] may possibly be an experiment by the political left in controlling people." Another woman stated, 
We've been told only pigs get coronavirus \& this is just a bacteria [sic]. The media is just trying to scare people and saying it's Trumps [sic] fault \& he don't [sic] care if we get sick \& that is not true. They don't want people to vote for Trump \& we need Trump to help out the Amish.

Table 4

Mention of Qualitative Themes by Election Status

\begin{tabular}{lcc}
\hline Theme & $\begin{array}{c}\text { Pre-Election } \\
(N=98) \\
n \text { (Percent) }\end{array}$ & $\begin{array}{c}\text { Post-Election } \\
(N=154) \\
n(\text { Percent) }\end{array}$ \\
\hline Faith & $20(20.4)$ & $33(21.4)$ \\
Politics & $18(18.4)$ & $19(12.3)$ \\
Flu & $35(35.7)$ & $30(19.5)$ \\
Blown & $37(37.8)$ & $36(23.4)$ \\
Fear & $12(12.2)$ & $20(13.0)$ \\
Masks & $14(14.3)$ & $19(12.3)$ \\
Chip & $9(9.2)$ & $6(3.9)$ \\
Media & $4(4.1)$ & $10(6.5)$ \\
Cure & $1(1.0)$ & $1(0.6)$ \\
Evil, Bad & $9(9.2)$ & $4(2.6)$ \\
Mistrust & $15(15.3)$ & $28(18.2)$ \\
\hline
\end{tabular}

On the other hand, post-election respondents mentioned politics 19 times (12.3\%) and wrote broader comments such as "I believe there are a lot of political issues involved with this" and "[W]e believe it is all about politics."

Many of the qualitative keywords were mentioned with similar frequency regardless of survey completion date and provided valuable insights into Amish perceptions of COVID-19. Respondents mentioned "faith" 53 times $(21.0 \%)$, with one woman stating, "If I get sick and die that is God's will, I want to be with Jesus forever." Other responses included "Let's not be so scared and trust in the Lord" and "I feel it's just something God let come. Let's just trust in Him."

When we asked participants about their willingness to get vaccinated, 175 (73.5\%) answered no, $59(24.8 \%)$ were unsure, and only $4(1.7 \%)$ answered yes. The qualitative themes of "chip" (i.e., computer chip in the vaccine) and "trust" were often used to explain negative vaccine perceptions. In pre-election responses, the word "chip" was mentioned 9 times $(9.2 \%)$ while postelection responses mentioned "chip" 6 times (3.9\%). Some comments also overlapped with the qualitative theme of faith, including this pre-election response: "And they also want to put the chips in (The beast) \& we do NOT want any of this." Post-election responses that mentioned a chip also related to faith: 
"[T] heir [sic] is a lets [sic] say rumor (or not) thing among us, that a computer chip is in the vaccine, Amish are very conctous [sic] of that, that we don't get the chip in our bodies. Revelation 14" and "I don't believe in it with chip I want my own identity [sic]. I want Jesus in my life."

We found only a slight increase post-election in the responses themed around trust in relation to vaccination, with $28(18.2 \%)$ respondents citing mistrust of the vaccine as a reason for their hesitancy as opposed to $15(15.3 \%)$ who mentioned mistrust pre-election. Vaccine hesitancy was often explained by lack of knowledge about the contents of the vaccine and the need for more long-term research, as these participants stated: "Because they say there is stuff in the vaccine that is not good for you" and "The vaccine hasn't been available long enough for long-term side effects to show up."

\section{Discussion}

Based on our survey results, hesitancy for the COVID-19 vaccine remained constant throughout the election period among Amish women living in settlements in Ohio, with around $75 \%$ of respondents stating that they would not immunize, even though the vast majority of respondents knew someone who was infected from the virus. These numbers changed little before and after the election. A study conducted in the same area in April 2020 yielded similar results, with around $75 \%$ of Amish respondents stating that they would not have their children vaccinated against COVID-19 (Scott et al., 2021). In a national survey in the United States conducted in June 2020 (Khubchandani et al., 2021), only 22\% expressed vaccine hesitancy. Of respondents living in rural regions, $29 \%$ of the national survey respondents were vaccine hesitant, which is a large difference from the percentage (73.5\%) who were not willing among Amish women in our study.

Many diseases for which the Amish exhibit low vaccination rates are preventable (Scott et al., 2021). Further, past research shows that Amish objections are not primarily based on fundamental religious beliefs per se, but on issues associated with the perceived efficacy of vaccines and their safety for human use (Grabenstein, 2013; Medina-Marino et al., 2013; Scott et al., 2021; Wenger et al., 2011; Yoder \& Dworkin, 2006). In other words, it is how information about medical issues more generally and vaccines more specifically is communicated within the Amish subculture that blends with their continued reliance on alternative medicine (e.g., folk remedies) and preference of waiting until an illness becomes acute before seeking professional health care to create a greater reluctance to readily embrace vaccinations. Plus, in many rural localities where Amish settlements are today, health care services are more limited, making access a factor (Blair \& Hurst, 1997; Hurst \& McConnell, 2010; Kraybill et al., 2013).

Qualitative analyses of the open-ended responses revealed a high degree of mistrust in the scientific community and the vaccine, an underestimation of perceived risk, and lack of access to COVID-19 testing and culturally sensitive health information. These outcomes help us understand the why behind vaccine hesitancy among Amish women and fit all categories of the $3 \mathrm{Cs}$ model that was first introduced to the World Health Organization EURO Vaccine Communications 
Working Group in 2011: confidence, complacency, and convenience (MacDonald, 2015). Understanding the key factors influencing vaccine hesitancy is a key first step in developing effective interventions aimed at reducing the impact of these categories and their inter- and intrarelationships in decision-making. However, more research is warranted to reveal how information about COVID-19 was obtained among Amish and other Plain Anabaptist communities. For example, the use of Amish "taxis" for transportation to medical and other services in nearby towns and for travel to other settlements for visiting, weddings, funerals, and other social occasions presents a new way for information to diffuse within an Amish population. Van drivers often have their radios tuned to conservative talk radio while transporting their Amish customers. How much does this new source of information influence Amish decision-making about vaccines and other medical issues? This could be an important direction for future research on Amish beliefs about medicine and illness.

One key limitation to the study is that only Amish women who participated in a previous women's mobile clinic received the survey. Women who participated in these clinics were already health-seeking and open to preventive health care practices aimed at reducing the burden of women's cancers and other health issues. Women from dozens of separate church districts participated in these screenings, with varying differences with respect to acceptance of modern technology and access to scientific reports and health resources. While we chose to aggregate the data for all Amish churches in this convenience sample, another study did find that more conservative church districts had higher vaccine hesitancy rates (Scott et al., 2021). Delineating church districts according to levels of acceptance of modern society may reveal distinct differences in how misinformation and disinformation are accessed and accepted, providing valuable input for a more tailored approach to health messages delivered by public health and clinical agencies. Indeed, the Amish are much more diverse than the general public and many health care professionals might imagine. Future research should focus on intra-Amish differences in both medical beliefs and relative acceptance of vaccinations.

Additional avenues for research include variations in beliefs by the age of the settlement (since so many are new, given their doubling time), the size of the settlement, and its location by state or region of North America. These characteristics may be significant for influencing how Amish learn about new development in illnesses and medical treatments.

\section{Conclusions}

A history of Amish hesitancy to accept vaccines once again displays itself in our survey about COVID-19 (Alexander et al., 2009; Briss et al., 1992; Fry et al., 2001; Gastanaduy et al., 2016; Grabenstein, 2013; Kettunen et al., 2017; Medina-Marino et al., 2013; Myers et al., 2017; Scott et al., 2021; Wenger et al., 2011; Yoder \& Dworkin, 2006). A real change in the Amish conversations about COVID-19 when compared to previous studies about the Amish is the greater politicized context of the disease and the efficacy of the vaccines. Previous research of the Amish points to the fact that Amish regard medical decisions to lie mostly within the individual family, and in turn, these decisions are influenced by their Amish neighbors, by members of their own church group, 
by the church discipline or Ordnung, and by the Amish preference to seek out alternative medical solutions (Blair \& Hurst, 1997; Hurst \& McConnell, 2010; Kraybill et al., 2013). Based on our results, there is now a more noticeable political undertone to possible objections. Even with a continuous stream of positive information about the benefits of vaccines and other forms of preventive medicine, Amish reluctance to participate in immunization initiatives will likely remain when compared to the general population.

\section{References}

Alexander, J. P., Ehresmann, K., Seward, J., Wax, G., Harriman, K., Fuller, S., Cebelinski, E. A., Chen, Q., Jorba, J., Kew, O. M., Pallansch, M. A., Oberste, M. S., Schleiss, M., Davis, J. P., Warshawsky, B., Squires, S., Hull, H. F., for the Vaccine-Derived Poliovirus Investigations Group. (2009). Transmission of imported vaccine-derived poliovirus in an undervaccinated community in Minnesota. Journal of Infectious Diseases, 199(3), 391-397.

https://doi.org/10.1086/596052

Blair, R. B., \& Hurst, C. E. (1997). Amish health care. Journal of Multicultural Nursing \& Health, 3(2), 38-44.

Bland, J. M., \& Altman, D. G. (2000). Statistics notes. The odds ratio. BMJ (Clinical Research Education), 320(7247), 1468. https://doi.org/10.1136/bmj.320.7247.1468

Briss, P. A., Fehrs, L. J., Hutcheson, R. H., \& Schaffner, W. (1992). Rubella among the Amish: Resurgent disease in a highly susceptible community. Pediatric Infectious Disease Journal, 11(11), 955-959. https://doi.org/10.1097/00006454-199211110-00010

Clarke, V., \& Braun, V. (2017). Thematic analysis. Journal of Positive Psychology, 12(3), 297298. https://doi.org/10.1080/17439760.2016.1262613

Clinton, J., Cohen, J., Lapinski, J., \& Trussler, M. (2021). Partisan pandemic: How partisanship and public health concerns affect individuals' social mobility during COVID-19. Science Advances, 7(2), eabd7204. https://doi.org/10.1126/sciadv.abd7204

Donnermeyer, J. F. (2021). How do I count thee? Various angles for examining the doubling times of the Amish. Journal of Plain Anabaptist Communities, 1(1), 104-125. https://doi.org/10.18061/jpac.v1i2.7990

Freudenburg, W. R. (1986). The density of acquaintanceship: An overlooked variable in community research? American Journal of Sociology, 92(1), 27-63. https://doi.org/10.1086/228462

Fry, A. M., Lurie, P., Gidley, M., Schmink, S., Lingappa, J., Fischer, M., \& Rosenstein, N. E. (2001). Haemophilus influenzae Type b disease among Amish children in Pennsylvania: reasons for persistent disease. Pediatrics, 108(4), e60. https://doi.org/10.1542/peds.108.4.e60

Gastanaduy, P. A., Budd, J., Fisher, N., Redd, S. B., Fletcher, J., Miller, J., McFadden, D. J., III, Rota, J., Rota, P. A., Hickman, C., Fowler, B., Tatham, L., Wallace, G. S., de Fijter, S., Parker Fiebelkorn, A., \& DiOrio, M. (2016). A measles outbreak in an underimmunized 
Amish community in Ohio. New England Journal of Medicine, 375(14), 1343-1354. https://doi.org/10.1056/NEJMoa1602295

Grabenstein, J. D. (2013). What the world's religions teach, applied to vaccines and immune globulins. Vaccine, 31(16), 2011-2023. https://doi.org/10.1016/j.vaccine.2013.02.026

Greksa, L. P. (2002). Population growth and fertility patterns in an Old Order Amish settlement. Annuals of Human Biology, 29(2), 192-201. https://doi.org/10.1080/03014460110075684

Heaton, T. B. (1986). How does religion influence fertility? The case of Mormons. Journal for the Scientific Study of Religion, 25(2), 248-258. https://doi.org/10.2307/1385480

Henslin, J. M. (2015). Essentials of sociology: A down-to-earth approach (11th ed.). Pearson. Hostetler, J. A. (1993). Amish society. Johns Hopkins University Press.

Huberman, A. M., \& Miles, M. B. (2002). The qualitative researcher's companion. SAGE Publications. https://doi.org/10.4135/9781412986274

Hurst, C. E., \& McConnell, D. L. (2010). An Amish paradox: Diversity and change in the world's largest Amish community. Johns Hopkins University Press.

Kettunen, C., Nemecek, J., \& Wenger, O. (2017). Evaluation of low immunization coverage among the Amish population in rural Ohio. American Journal of Infection Control, 45(6), 630-634. https://doi.org/10.1016/j.ajic.2017.01.032

Khubchandani, J., Sharma, S., Price, J. H., Wiblishauser, M. J., Sharma, M., \& Webb, F. J. (2021). COVID-19 vaccination hesitancy in the United States: A rapid national assessment. Journal of Community Health, 46(2), 270-277. https://doi.org/10.1007/s10900-020-00958-X

Kraybill, D. B., Johnson-Weiner, K. M., \& Nolt, S. M. (2013). The Amish. Johns Hopkins University Press.

MacDonald, N. E. (2015). Vaccine hesitancy: Definition, scope and determinants. Vaccine, 33(34), 4161-4164. https://doi.org/10.1016/i.vaccine.2015.04.036

Medina-Marino, A., Reynolds, D., Finley, C., Hays, S., Jones, J., \& Soyemi, K. (2013).

Communication and mass vaccination strategies after pertussis outbreak in rural Amish communities - Illinois, 2009-2010. Journal of Rural Health, 29(4), 413-419.

https://doi.org/10.1111/jrh.12019

Myers, A. L., Jackson, M. A., Zhang, L., Swanson, D. S., \& Gilsdorf, J. R. (2017). Haemophilus influenzae Type b invasive disease in Amish children, Missouri, USA, 2014. Emerging Infectious Disease, 23(1), 112-114. https://doi.org/10.3201/eid2301.160593

Naeim, A., Baxter-King, R., Wenger, N., Stanton, A. L., Sepucha, K., \& Vavreck, L. (2021). Effects of age, gender, health status, and political party on COVID-19-related concerns and prevention behaviors: Results of a large, longitudinal cross-sectional survey. JMIR Public Health and Surveillance, 7(4), e24277. https://doi.org/10.2196/24277

Nikolaidis, A., Paksarian, D., Alexander, L., Derosa, J., Dunn, J., Nielson, D. M., Droney, I., Kang, M., Douka, I., Bromet, E., Milham, M., Stringaris, A., \& Merikangas, K. R. (2020). The Coronavirus Health and Impact Survey (CRISIS) reveals reproducible correlates of pandemic-related mood states across the Atlantic. medRxiv.

https://doi.org/10.1101/2020.08.24.20181123 
Nolt, S. M. (2015). A history of the Amish (3rd ed.). Good Books.

Scott, E. M., Stein, R., Brown, M. F., Hershberger, J., Scott, E. M., \& Wenger, O. K. (2021). Vaccination patterns of the northeast Ohio Amish revisited. Vaccine, 39(7), 1058-1063. https://doi.org/10.1016/j.vaccine.2021.01.022

Stark, R., \& Bainbridge, W. S. (1979). Of churches, sects and cults: Preliminary concepts for a theory of religious movements. Journal for the Scientific Study of Religion, 18(2), 117-131. https://doi.org/10.2307/1385935

Wasao, S. W., \& Donnermeyer, J. F. (1996). An analysis of factors related to parity among the Amish in Northeast Ohio. Population Studies, 50(2), 235-246. https://doi.org/10.1080/0032472031000149326

Wenger, O. K., McManus, M. D., Bower, J. R., \& Langkamp, D. L. (2011). Underimmunization in Ohio's Amish: Parental fears are a greater obstacle than access to care. Pediatrics, 128(1), 79-85. https://doi.org/10.1542/peds.2009-2599

Williamson, G., Ahmed, B., Kumar, P. S., Ostrov, B. E., \& Ericson, J. E. (2017). Vaccinepreventable diseases requiring hospitalization. Pediatrics, 140(3) e20170298. https://doi.org/10.1542/peds.2017-0298

Wilson, B. (1982). Religion in sociological perspective. Oxford University Press.

Yoder, J. S., \& Dworkin, M. S. (2006). Vaccination usage among an Old-Order Amish community in Illinois. Pediatric Infectious Disease Journal, 25(12), 1182-1183. https://doi.org/10.1097/01.inf.0000246851.19000.3e 